\title{
Thyroid hormones in small ruminants: effects of endogenous, environmental and nutritional factors
}

\author{
L. Todini \\ Dipartimento di Scienze Ambientali - Sezione di Produzioni Animali, Università di Camerino, Via della Circonvallazione 93/95, 62024 Matelica (MC), Italy
}

(Received 26 October 2006; Accepted 16 April 2007)

\begin{abstract}
Appropriate thyroid gland function and thyroid hormone activity are considered crucial to sustain the productive performance in domestic animals (growth, milk or hair fibre production). Changes of blood thyroid hormone concentrations are an indirect measure of the changes in thyroid gland activity and circulating thyroid hormones can be considered as indicators of the metabolic and nutritional status of the animals. Thyroid hormones play a pivotal role in the mechanisms permitting the animals to live and breed in the surrounding environment. Variations in hormone bioactivity allow the animals to adapt their metabolic balance to different environmental conditions, changes in nutrient requirements and availability, and to homeorhetic changes during different physiological stages. This is particularly important in the free-ranging and grazing animals, such as traditionally reared small ruminants, whose main physiological functions (feed intake, reproduction, hair growth) are markedly seasonal. Many investigations dealt with the involvement of thyroid hormones in the expression of endogenous seasonal rhythms, such as reproduction and hair growth cycles in fibre-producing (wool, mohair, cashmere) sheep and goats. Important knowledge about the pattern of thyroid hormone metabolism and their role in ontogenetic development has been obtained from studies in the ovine foetus and in the newborn. Many endogenous (breed, age, gender, physiological state) and environmental factors (climate, season, with a primary role of nutrition) are able to affect thyroid activity and hormone concentrations in blood, acting at the level of hypothalamus, pituitary and/or thyroid gland, as well as on peripheral monodeiodination. Knowledge on such topics mirror physiological changes and possibly allows the monitoring and manipulation of thyroid physiology, in order to improve animal health, welfare and production.
\end{abstract}

Keywords: goats, nutrition, seasons, sheep, thyroid hormones

\section{Introduction}

Appropriate thyroid gland function and activity of thyroid hormones $(\mathrm{TH})$ are considered crucial to sustain the productive performance in domestic animals (growth, milk, hair fibre production) and circulating TH can be considered as indicators of the metabolic and nutritional status of the animals (Riis and Madsen, 1985; Todini et al., 2007). Changes of blood TH concentrations are an indirect measure of the changes in thyroid gland activity. Many papers report marked seasonal variation in thyroid activity and in blood TH concentration. These hormone variations are particularly important in the free-ranging and grazing animals, whose main physiological functions (feed intake, reproduction, hair growth) are markedly seasonal. This is the case of small ruminants traditionally reared. Such variations in hormone concentration, in fact, allow the animals

E-mail: luca.todini@unicam.it to adapt their metabolic balance to different environmental conditions, variations in nutrient requirements and availability, and to homeoretic changes during different physiological stages.

The present paper aims to review and summarise literature data about actions specifically described in domestic small ruminants and the effects that several factors may exert on thyroid activity and circulating $\mathrm{TH}$. Endogenous factors (breed, age, gender, physiological state), environmental factors (climate, season) and nutrition are considered. Many other particular conditions are well known to alter thyroid functions in small ruminants, but they are not discussed in the present paper as they are not physiological: illness, iodine excess or deficiency, ingestion of goitrogenic substances, phytoestrogens and other endocrine-disrupting compounds, exogenous hormones or drugs intake. The values of blood hormone concentrations are characterised by an extreme variability, which is of course very meaningful in each particular study. On the other hand, values 
reported in different papers are not comparable due to the very large differences of the experimental animals and conditions, as well as assay methods. For this reason, the author's choice was not to report the absolute numerics of hormone values in the text.

\section{Overview of thyroid hormone physiology}

$\mathrm{TH}$, tetra-iodothyronine or thyroxine (T4) and 3-5-3'-triiodothyronine (T3), are iodinated derivatives from the amino acid tyrosine. T4 can be deiodinated to the biologically active hormone $\mathrm{T} 3$ by a $5^{\prime}$-deiodinase enzyme (outerring deiodination), and to the inactive reverse $\mathrm{T3}$ (rT3) by the enzyme 5-deiodinase (inner-ring deiodination) (Utiger, 1995). Thyroid gland of adult sheep contains about $90.4 \%$, $8.8 \%$ and $0.7 \%$ of $\mathrm{T} 4, \mathrm{~T} 3$ and $\mathrm{rT} 3$, respectively, and $\mathrm{T} 4$ is the main secretory product (about 77\%) (Chopra et al., 1975). In adult sheep more than $99.9 \%$ of T4 and $99.5 \%$ of T3 circulate in blood bound to plasma proteins (Chopra et al., 1975). Only the free hormone is responsible for the biological activity and protein-bound hormones function as a promptly utilisable storage, delaying the effects of decreased thyroid secretion, as well as buffer against sudden increases in thyroid's secretory activity (Bartalena, 1990; Utiger, 1995).

Small amounts of the active hormone T3 come from the thyroid, but in adult sheep at least $50 \%$ of serum $\mathrm{T} 3$ and $97 \%$ of serum rT3 derive from monodeiodination of T4 in peripheral tissues (Fisher et al., 1972; Chopra et al., 1975). Deiodination can occur in most if not all tissues, but the liver and the kidney show the highest deiodinating activity. lodothyronine deiodinase enzymes are selenoproteins and show structural differences and different tissue distribution between various species (Santini et al., 1992; Nicol et al., 1994; Chadio et al., 2006). Type I is predominantly expressed in the liver and kidney; it is inhibited by propylthiouracil (PTU) and stimulated by T3. The type II enzyme is predominant in the brain, pituitary, skin, skeletal muscle, brown adipose tissue; it is not sensitive to PTU, but it is inhibited by rT3 and T4 (Kohrle, 1999). Type III monodeiodinase is a 5-deiodinase, which catalyses the transformation of T3 to 3-3'-diiodothyronine (T2) and of T4 to rT3. The latter does not bind to the nuclear receptor and is considered biologically inactive, but it is a powerful inhibitor of type II deiodinase (Kaiser et al., 1986) and decreases oxygen consumption and ATP/ADP ratio (Okamoto and Leibfritz, 1997). Type III is widely distributed throughout the body, playing an important role in regulating TH homeostasis and bioavailability (Bianco et al., 2002; Bianco and Kim, 2006). It is particularly expressed in the placenta, in the pregnant uterus and in foetal tissues, limiting $\mathrm{TH}$ bioactivity and playing a critical role in the development and maturation of the thyroid axis of the foetus and newborn animal (Galton, 2005; Hernandez et al., 2006). The functions and regulation of the different deiodinase activities are also a mean for allowing the organism to adapt to changing states such as iodine deficiency or chronic illness (Wartofsky and Burman, 1982; Chopra et al., 1985). Earlier, diiodothyronines also were considered inactive metabolites, but recently their thermogenic actions have been highlighted (Moreno et al., 2002).

TH are mostly inactivated by glucuronidation in the liver and secretion into bile, or by sulphation and deiodination in the liver or kidney (Chopra et al., 1978). Oxidative deamination and decarboxylation occurring in the kidney, liver and muscle, form acid metabolites, which maintain a certain biological activity, but do not contribute to the hormone action in euthyroid subjects because they are produced in very small amounts (Greenspan, 2001). Decarboxylated derivatives of iodothyronines, such as monoiodothyronamine and thyronamine, actually represent a very interesting field of investigation, because they may have some biological actions, even different from those of $\mathrm{TH}$ (Wu et al., 2005).

Thyroid cell growth and all the steps in the synthesis and secretion of $\mathrm{TH}$ are stimulated by the pituitary glycoprotein thyrotropin (TSH). TSH synthesis and release are in turn stimulated by the hypothalamic tripeptide TSH-releasing hormone (TRH). The hypothalamus controls the pituitary thyrotrophs also by inhibiting factors (somatostatin, dopamine). Increased plasma levels of TH exert a negative feedback control on both the pituitary and the hypothalamus (Utiger, 1995). Many factors are able to affect thyroid activity and hormone concentrations in blood, acting at the level of hypothalamus, pituitary and/or thyroid gland, as well as on peripheral monodeiodination (Figure 1). In addition, growth factors, prostaglandins, cytokines, by means of paracrine and/or autocrine actions, may modify thyroid cell growth and activity (Greenspan, 2001).

TH acts on many different target tissues, stimulating oxygen utilisation and heat production in every cell of the body. The overall effects are to increase the basal metabolic rate, to make more glucose available to cells, to stimulate protein synthesis, to increase lipid metabolism and to stimulate cardiac and neural functions (Capen and Martin, 1989). Peculiar actions consist in cell and tissue differentiation. TH are the primary endocrine stimulators of non-shivering ('facultative' or 'adaptive') thermogenesis, thus regulating body temperature (Silva, 2005). One main mechanism of this function should be the stimulation of expression and activity of uncoupling proteins (UCPs), which uncouple re-oxidation of reduced coenymes to ADP phosphorylation, hence producing heat (Collin et al., 2005). UCPs have been found in various tissues, also in ovine species (Darby et al., 1996; Mostyn et al., 2003). Most of the physiological actions of $\mathrm{TH}$ are mediated by the binding to nuclear receptors. Recently, several membrane transporters for cellular entry have been identified and they are now considered among the factors on which TH biological activity could depend (Hennemann et al., 2001; Friesema et al., 2005). As it is the case of steroid hormones some actions of TH are rapid and non-genomic (Davis et al., 2002; Hiroi et al., 2006) due to actions on mitochondria and cell 


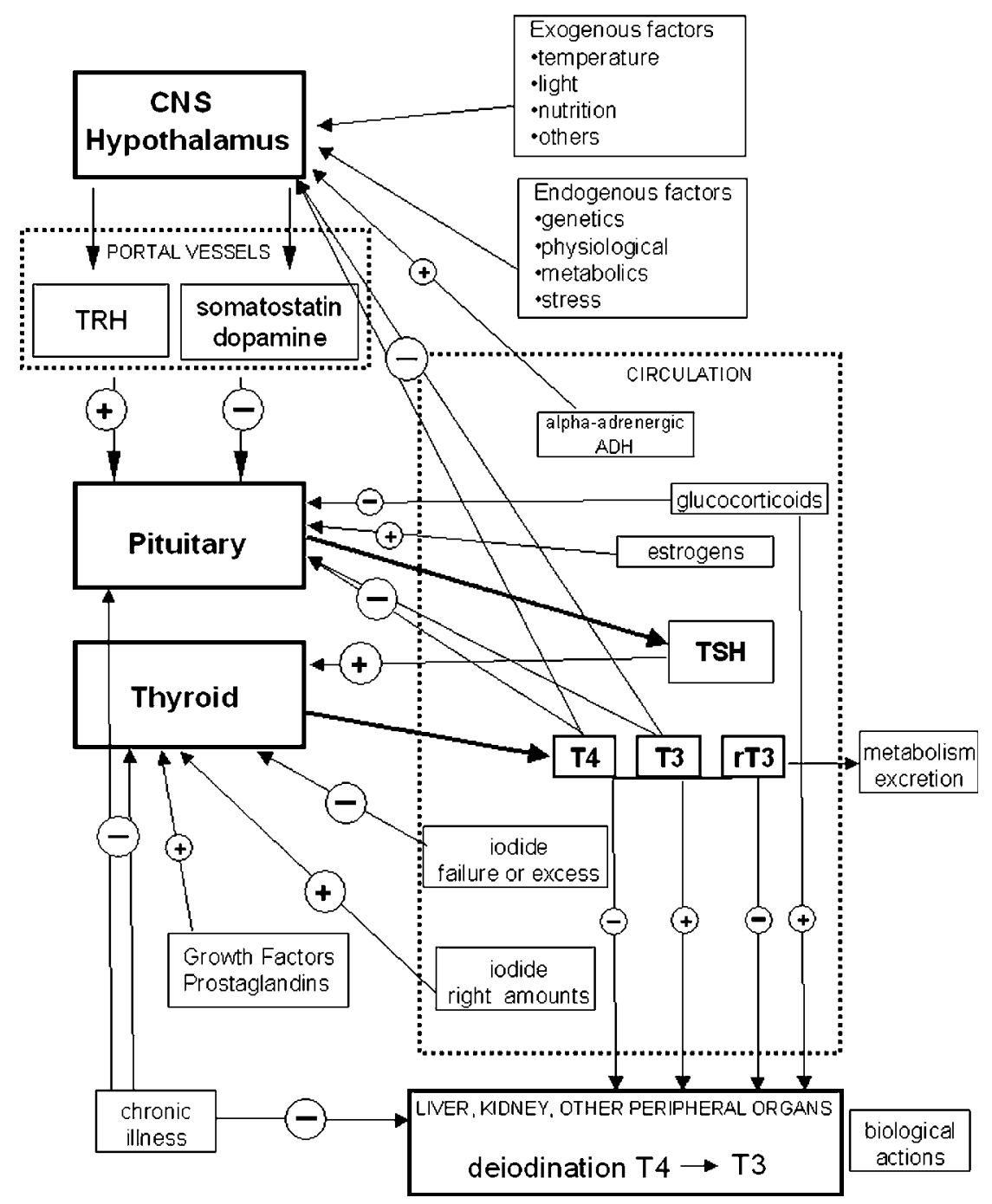

Figure 1 Schematic representation of the regulation of thyroid gland and thyroid hormones activity.

membranes on which binding proteins have been identified (Wrutniak-Cabello et al., 2001; Davis et al., 2005).

\section{Seasonality of reproduction}

In ovine species, a notable interest has been excited by the involvement of $\mathrm{TH}$ in seasonal reproduction (Karsch et al., 1995). In fact, TH play an important function in the expression of endogenous seasonal rhythms of neuroendocrine reproductive activity in sheep, as in many species of birds (Nicholls et al., 1988b). Thyroidectomised ewes began their sexual season at the same time as intact animals, but continued to cycle when the intact ewes enter seasonal anoestrus (Nicholls et al., 1988a; Maurenbrecher and Barrell, 2003). Similar but less-pronounced effects have been obtained in sheep rendered hypothyroid, in which the end of the reproductive season occurred later than in controls (Follett and Potts, 1990; Hernandez et al., 2003). $\mathrm{TH}$ are necessary during a limited period late in the breeding season to permit transition to seasonal anoestrus (Thrun et al., 1996 and 1997a), acting primarily within the brain to promote inhibition of neuroendocrine reproductive function (Viguié et al., 1999). TH permit the increase of the responsiveness to the oestradiol negative feeback, but are also required for steroid-independent seasonal cycles in luteinising hormone pulse frequency (Anderson et al., 2002). This permissive role of TH seemed limited to changes related to transition to seasonal anoestrus, since thyroidectomy during anoestrus did not affect the onset of the subsequent breeding season (Thrun et al., 1997b). Anyway, TH may be required for the long-term expression and maintenance of the endogenous seasonal reproductive rhythm (Billings et al., 2002).

In male sheep, thyroidectomy abolished seasonal cycles of gonadotropin secretion and testicular size (Parkinson and Follett, 1994; Parkinson et al., 1995).

The anatomical substrate for $\mathrm{TH}$ action on seasonal reproduction may be provided by the finding of TH receptor in $\mathrm{GnRH}$ and other neurotransmitters-containing neurons 
Todini

(Jansen et al., 1997). Recently, it has been found that photoperiod regulates the expression of type II deiodinase gene in the mediobasal hypothalamus of the Saanen goat, hence seasonally affecting the bioavailability of TH for the reproductive neuroendocrine axis (Yasuo et al., 2006).

To our knowledge, there is only one report about the requirement of $\mathrm{TH}$ in seasonal reproduction in goat species, and these results are in contrast with the above-mentioned numerous investigations carried on in sheep: Cashmere goats thyroidectomised in late breeding season advanced the onset of seasonal anoestrus (Walkden-Brown et al., 1996). Furthermore, T3 at the goat testis level induces the synthesis of a soluble protein in Leydig cells, which in turn stimulates androgen release (Jana and Bhattacharya, 1994; Jana et al., 1996).

\section{Hair fibre growth}

At the skin level, the availability of bioactive TH may depend not only on the circulating hormone levels but also on the local synthesis of T3. Type II and III, but not type I, deiodinase activity was detected in skin samples from cashmere goats (Villar et al., 1998 and 2000b) and showed marked individual variability between animals and seasonal changes. Type II deiodinase enzyme was higher during winter short-day photoperiod and lower during periods of long daylength, whereas type III showed an opposite pattern. Manipulations of circulating prolactin affected further the seasonal changes in the ratios of type II and type III deiodinase enzymes, and this was associated with differences in follicle activity and cashmere moult (Rhind et al., 2004). In Soay sheep, showing marked seasonal variations in hair growth rate, the quiescent period corresponded to the seasonal physiological decline in plasma TH concentrations (Lincoln et al., 1980). Studies correlating seasonal changes of plasma $\mathrm{TH}$ and cashmere growth cycle failed to ascertain the putative regulatory role of $\mathrm{TH}$ (Kloren et al., 1993) and contrasting results have been reported (Rhind and McMillen, 1995; Merchant and Riach, 2002; Celi et al., 2003; Rhind and Kyle, 2004). To clarify the role of TH on hair fibre production, many investigations have been carried out on manipulating $\mathrm{TH}$ availability for hair growth: on the whole, also the results of such papers were often contradictory (Ryder, 1979; Maddocks et al., 1985; Hynd, 1994; Rhind and McMillen, 1996). It seems that the sensitivity to TH failure or excess may be dependent on breed, season and interactions with other regulatory factors. TH action may be permissive rather than inductive, i.e. they might be present above certain threshold levels. Very important should be the interactions with other factors: firstly prolactin (Villar et al., 2000a; Rhind et al., 2004), as well as the local actions of insulin (Puchala et al., 1998) and growth factors, such as EGF (Hoath et al., 1983). The putative effects of $\mathrm{TH}$ on hair fibre diameter are very interesting from a commercial and technological viewpoint. In an earlier study, it was reported that exogenous T4 administration to intact sheep induced increased wool growth, in terms of increased fibre length, without affecting the diameter (Hart, 1957). T4, but not T3, reduced fibre diameter in sheep supplemented with selenium (Donald et al., 1994) but T4 administration failed to avoid the increase in wool diameter following increased feed intake (Lee et al., 2001). Angora goats rendered hyperthyroid by daily subcutaneous injections of T4 showed increased mohair growth, with higher fibre length and lower fibre diameter (Puchala et al., 2001). In Angora kids supplemented with energy and protein (horse bean), the higher plasma TH were associated with increased fibre length, decreased fibre diameter and higher percentage of active secondary follicles than controls (Todini et al., 2005). Anyway, further investigations are needed in order to clarify the role of $\mathrm{TH}$ in hair fibre production. This role should be rather different between animals showing a marked seasonality and clear moulting cycles (such as cashmere goats) and animals whose hair growth is more or less continuous throughout the year (Angora goats, Merino sheep).

\section{Foetal life}

In foetal sheep, during the last one-third period of gestation, serum T4 concentrations were slightly higher or comparable with those in adult sheep, while foetal serum T3 were much lower and rT3 much higher. The elevated rT3 concentrations in foetal sheep serum decreased progressively after birth and reached comparable levels with those in adults, within few days of life (Chopra et al., 1975). An opposite trend was described for T3 concentrations (Nathanielsz et al., 1973; Klein et al., 1978). These differences in serum hormone concentrations have been related to differences in peripheral deiodinase activity as the relative thyroidal content of T4 and T3 was similar in foetal and adult sheep (Chopra et al., 1975). In fact, type I deiodinase activity in the liver and kidney of foetus up to the fourth month was lower than that in pre-term foetus or in the newborn (Wu et al., 1992). Low foetal T3 levels are maintained also by sulphation and deiodination (Wu et al., 2006). In the foetus, low T3 levels allow anabolic processes to prevail, despite the high rate of foetal T4 secretion, which resulted eight-fold than maternal one during the last one-third period of gestation (Dussault et al., 1971). The pre-partum cortisol surge increased hepatic renal and perirenal adipose tissue type I deiodinase, and reduced renal and placental type III deiodinase activities (Forhead et al., 2006). The increased availability of active T3 is important for the latter phases of tissue differentiation. The functional development of brown adipose tissue allows to optimise non-shivering thermogenesis, thus permitting an adequate thermoregulation in the newborn (Schermer et al., 1996). Therefore, UCP1, induced by $T H$, is of primary importance for the transition from foetal to neonatal life, when cellular energy and thermoregulatory requirements are at maximal rates (Symonds et al., 2003). When the 
pre-partum rise of cortisol occurs, TH may also influence the growth and development of foetal liver and skeletal muscle, modulating the local activity of the somatotropic axis, i.e. the local expression of growth hormone receptor and insulin-like growth factors (Forhead et al., 1998, 2000 and 2002). At the same time TH are essential for foetal glucogenesis (Fowden et al., 2001), allowing the pre-partum rise in glucose-6-phosphatase and phosphoenolpyruvate carboxykinase activity in the foetal liver and kidney Forhead et al., 2003).

\section{Age effects: birth, neonatal period and growth. Gender effects}

The pre-partum cortisol rise is accompanied by an increase in foetal T3 and a decrease in rT3 concentrations (Sensky et al., 1994). This pattern should be maintained throughout the early postnatal life (Nathanielsz et al., 1973; Klein et al., 1978). Plasma free T3 (fT3) in neonatal lambs increased parallel to total T3 (Cabello and Wrutniak, 1986), whereas the neonatal increase of free T4 (fT4) concentrations was greater and longer lasting than total T4 (Cabello and Wrutniak, 1990). In fact, neonatal plasma T3 and fT4 rises followed that of TSH concentrations, lasting for $24 \mathrm{~h}$ after birth, but T4 levels declined before (after $2 \mathrm{~h}$ of life), when TSH levels were still elevated (Cabello and Wrutniak, 1990). Therefore, the thyroid gland seems unable to respond, in terms of T4 secretion, to a prolonged stimulation by TSH, probably because a depletion of hormonal stores in the gland occurs during the first minutes of life (Slebodzinski, 1972). It is likely that during the first hours of life the thyroid gland can respond to other stimulating factors: small increases of plasma TH followed exogenous prolactin administration in neonatal lamb, but not in growing lambs and ewes (Peeters et al., 1992). Plasma rT3 levels during the first $48 \mathrm{~h}$ of life progressively decreased in suckling lambs, but increased in bottle-fed lambs (Cabello and Wrutniak, 1986 and 1990). Plasma T4 concentrations were higher in single lambs than in twins at birth (Assane and Sere, 1990). Plasma TH levels highly correlated with lambs' birth-weight (Dwyer and Morgan, 2006) and were lower in lambs separated from their mothers just after parturition than in those maintained with their mothers (Firat et al., 2005). Neonatal lambs had higher levels of $T 3$ and T4 compared with growing lambs and ewes (Peeters et al., 1992). Growing goat kids displayed higher TH levels than adults (Colavita et al., 1983) and the lowest values were found in elderly animals (Table 1; Lucaroni et al., 1989). Age-related differences were particularly evident during the hot season, especially for T3 blood concentrations (Lucaroni et al., 1989).

In young animals, there is no sex-dependent differences in blood TH concentrations, whereas in adult goats mean plasma TH levels were higher (significantly for T4) in does than in bucks (Table 2; Todini et al., 1992). In young cashmere goats, T3 levels were lower in males than in females after 8 months of age, while T4 was not affected by
Table 1 Serum thyroid hormone concentrations (mean \pm s.d.) in goats (local Umbrian population) at different ages (data grouped from samplings at different seasons), adapted from Lucaroni et al. (1989)

\begin{tabular}{cccc}
\hline \hline Age (years) & $n$ & $\mathrm{~T} 3(\mathrm{ng} / \mathrm{ml})$ & $\mathrm{T} 4(\mu \mathrm{g} / \mathrm{dl})$ \\
\hline$<1$ & 33 & $2.82 \pm 1.01$ & $8.65 \pm 1.86$ \\
1 & 68 & $2.75 \pm 1.20$ & $6.93 \pm 2.08$ \\
2 & 47 & $2.57 \pm 1.49$ & $6.35 \pm 1.63$ \\
3 & 74 & $1.93 \pm 0.74$ & $7.04 \pm 1.36$ \\
4 & 79 & $1.78 \pm 0.79$ & $6.98 \pm 1.50$ \\
5 & 111 & $1.73 \pm 0.73$ & $6.93 \pm 1.71$ \\
$>6$ & 107 & $1.57 \pm 0.62$ & $5.67 \pm 1.81$ \\
\hline \hline
\end{tabular}

sex (Celi et al., 2003). Sex-related differences are reported in others mammals and are referred to several actions by sexual steroid hormones: differences in total T4 levels can be explained by oestrogen-reduced catabolism of thyroxinebinding globulin (TBG) (Ain et al., 1987), or androgen inhibition of the synthesis of TBG by the liver (Federman et al., 1958). Moreover, androgens inhibit TSH secretion by the pituitary (Christianson et al., 1981).

\section{Breed effects}

To our knowledge, there are no published data on goat breed differences. At birth, Blackface lambs had higher T3 and T4 levels than Suffolk lambs and this was correlated with higher body temperature and better thermoregulatory ability (Dwyer and Morgan, 2006). Merino lambs aged 2 to 3 days, submitted to cold stress, showed a stronger increase of TH levels compared with Romney-Marsh lambs (Doubek et al., 2003). Lamb breeds that are usually reared under extensive conditions (hill regions) have an improved thermoregulation than those reared intensively in lowland: this is partly related to birthcoat characteristics, accompanied by higher TH concentrations (important for endogenous heat production and hair growth) in hill than lowland lambs (Dwyer and Lawrence, 2005). Assaf ewes had higher serum T4 concentrations than Rasa Aragonesa and Merino ewes, which was associated with differences in wool growth rate (Abecia et al., 2005). Higher plasma T4 levels in Suffolk ewes than Gulf Coast native ewes in the US were shown to be positively related to larger body size and enhanced growth potential (Williams et al., 2004). Higher levels of T3 and $\mathrm{T} 4$ in ram lambs have been associated with higher prolificacy of the Outaouais breed compared with the Suffolk breed (lower prolificacy) (Fallah-Rad and Connor, 1999). The decline in serum T4 levels induced by feed restriction was greater in crossbreed ewes than in native Indian sheep (Naqvi and Rai, 1991).

\section{Changes during oestrus, pregnancy, peri-parturient period and lactation}

During induced or spontaneous oestrus in goats, a rise in plasma total T4 (Colavita and Malfatti, 1989) and 
Todini

Table 2 Plasma thyroid hormone concentrations (mean \pm s.d.) in 16 adult does and 8 adult bucks (dairy Mediterranean breeds), maintained sexseparated and fed a qualitatively constant diet throughout the year (weekly samplings). Monthly mean, minimal and maximal environmental temperatures are also indicated (adapted from Todini et al. (1992)).

\begin{tabular}{|c|c|c|c|c|c|c|c|}
\hline & \multicolumn{2}{|c|}{ Does } & \multicolumn{2}{|c|}{ Bucks } & \multicolumn{3}{|c|}{ Environmental temperature $\left({ }^{\circ} \mathrm{C}\right)$} \\
\hline & T3 (ng/ml) & $\mathrm{T} 4(\mu \mathrm{g} / \mathrm{dl})$ & $\mathrm{T} 3$ (ng/ml) & $\mathrm{T} 4(\mu \mathrm{g} / \mathrm{dl})$ & Minimum & Maximum & Mean \\
\hline Jan. & $0.96 \pm 0.29$ & $7.90 \pm 3.35$ & $0.88 \pm 0.31$ & $4.83 \pm 0.89$ & 0.4 & 11.8 & 6.1 \\
\hline Feb. & $0.84 \pm 0.31$ & $7.50 \pm 3.66$ & $0.84 \pm 0.16$ & $5.40 \pm 1.53$ & 2.7 & 16.8 & 9.7 \\
\hline Mar. & $1.10 \pm 0.43$ & $8.15 \pm 2.22$ & $0.75 \pm 0.17$ & $4.40 \pm 0.86$ & 2.0 & 17.2 & 9.6 \\
\hline Apr. & $1.35 \pm 0.40$ & $7.55 \pm 3.55$ & $0.83 \pm 0.04$ & $5.72 \pm 1.38$ & 7.3 & 19.7 & 13.5 \\
\hline May & $0.95 \pm 0.23$ & $6.34 \pm 2.01$ & $0.79 \pm 0.10$ & $5.16 \pm 0.95$ & 9.1 & 24.7 & 16.9 \\
\hline Jun. & $0.84 \pm 0.20$ & $7.07 \pm 3.27$ & $0.82 \pm 0.22$ & $4.41 \pm 0.72$ & 12.9 & 28.3 & 20.60 \\
\hline Jul. & $0.59 \pm 0.12$ & $6.10 \pm 2.47$ & $0.69 \pm 0.06$ & $3.88 \pm 0.79$ & 16.5 & 32.3 & 24.4 \\
\hline Aug. & $0.71 \pm 0.23$ & $6.82 \pm 2.32$ & $0.50 \pm 0.08$ & $4.09 \pm 1.30$ & 15.8 & 30.3 & 23.0 \\
\hline Sep. & $0.63 \pm 0.14$ & $6.80 \pm 3.17$ & $0.58 \pm 0.06$ & $3.75 \pm 0.81$ & 12.1 & 26.5 & 19.3 \\
\hline Oct. & $0.78 \pm 0.19$ & $7.05 \pm 2.75$ & $0.82 \pm 0.13$ & $4.31 \pm 1.20$ & 6.6 & 21.2 & 16.9 \\
\hline Nov. & $0.85 \pm 0.20$ & $7.28 \pm 2.47$ & $0.95 \pm 0.14$ & $5.00 \pm 0.89$ & 4.5 & 15.3 & 9.9 \\
\hline Dec. & $0.88 \pm 0.33$ & $7.61 \pm 3.15$ & $0.98 \pm 0.27$ & $5.11 \pm 1.27$ & 2.2 & 13.3 & 7.7 \\
\hline Year & $0.87 \pm 0.32$ & $7.17 \pm 2.89$ & $0.79 \pm 0.19$ & $4.65 \pm 1.17$ & & & \\
\hline
\end{tabular}

fT4 (Blaszczyk et al., 2004) levels has been observed. In ewes, plasma T4 levels were higher during oestrus and lower during the luteal phase, T3 concentrations were higher during the luteal phase, while the concentrations of rT3 were not associated with the oestrous cycle (Peeters et al., 1989).

During pregnancy, thyroid activity and circulating hormone levels are reported to increase in all the investigated mammalian species. Several mechanisms have been claimed to explain these observations: increased binding protein concentrations in plasma, secretion of thyrotropic factors by the placenta, enhanced responsiveness of pituitary TSH secretion to hypothalamic TRH and changes in maternal TH catabolism (De Leo et al., 1998; Glinoer, 2001). Towards the end of pregnancy, the goat foetus(es) should play a competitive role (higher thyroid activity, iodine affinity and uptake than maternal ones), so that a decrease in maternal plasma fT4 concentrations has been observed (McDonald et al., 1988). Plasma T3 and T4 levels in goats at mid-pregnancy rised compared with the low levels observed just before oestrus and mating. Then, during the second half of pregnancy, maternal hormone levels progressively decrease, probably because of the negative energy balance (Todini et al., 2007). This is supported by the lower maternal serum TH levels (more marked and significant for T4) observed in twin-bearing does, that are often characterised by negative energy balance, compared with aborted and single-bearing does (whose energy balance is usually less negative) (Manalu et al., 1997). Very similar findings are reported for ewes. Plasma T4 concentration was highest during early pregnancy and decreased gradually, reaching lowest values during late pregnancy and post partum (Assane and Sere, 1990; Okab et al., 1993; Yildiz et al., 2005). Like in goats, maternal T3 and T4 in twin pregnancy were lower compared with single-bearing sheep (Yildiz et al., 2005), especially at the end of pregnancy (Assane and Sere, 1990).

In goats, maternal plasma T3 levels remained rather steady around parturition, while T4 concentrations markedly decreased and remained low until day 10 post partum (Lucaroni and Todini, 1989). Khan and Ludri (2002b) reported that both $\mathrm{TH}$ concentrations did not change from day 20 before parturition until the day of kidding, when they reached a minimal level, followed by an increase until day 20 post partum. In ewes, plasma TH concentrations were lower post partum than during pregnancy (Okab et al., 1993), tended to decrease from $36 \mathrm{~h}$ to 21 days post partum and thereafter constantly rose until day 51 post partum (Bekeova et al., 1991).

Blood TH levels were low at the beginning of lactation, afterwards gradually rose in does (Riis and Madsen, 1985; Emre and Garmo, 1985) and in ewes (Mitin et al., 1986). Administration of TH is known to stimulate lactation in many species (Tucker, 1994 and 2000) but an inverse relationship between blood hormone concentration and milk yield has been observed in goats (Riis and Madsen, 1985), at least during the first phases of lactation. In ewes, during late lactation, the increase of T4 concentration in blood seems related to the decrease of milk production (Bass, 1989).

Within the first 20 days post partum, in twin-bearing does, plasma TH levels were significantly lower compared with single-bearing does (Khan and Ludri, 2002a), but throughout lactation very slight or no differences between single and twin-suckling ewes were found (Bass, 1989; Rhind et al., 1991). Taken together, these findings may support the meaning of blood TH levels as indicators of the energy balance, also in lactating animals. 


\section{Circadian rhythms}

Circadian changes in hormone secretion are probably associated with the rhythms of environmental temperature and light, as well as with feed intake and metabolism, which in turn are related to the alternance activity/rest throughout the day. Moreover, overlapping effects by season and physiological state are expected. Because many factors can influence T4 and T3 levels and because interactions between these factors are likely, the few data available in the literature on such topics are rather discordant.

Blood samplings at 4-h intervals in late spring did not permit to find significant circadian differences in TH concentrations in lactating (milked or suckled) goats, but the maximal levels were observed during the night (Lucaroni et al., 1989). In ewes sampled twice a day, the differences between morning and afternoon were not univocal, depending on the season (Ashutosh et al., 2001). In ewes sampled at 2-h intervals, lowest blood hormone levels were found in the afternoon, concentrations then increased progressively during the night, and reached the highest levels in the morning (Velasquez et al., 1997). In winter, T3 and T4 concentrations reached maximal levels in early morning, probably because of a delayed response to cold stress to which the animals were exposed by night; furthermore, the circadian variations in winter decreased with the increase in wool length (Salem et al., 1991). Combining the results obtained from samplings carried out every 2 months for 1 year, rams showed the highest TH concentrations during the afternoon and the lowest in the early morning (Souza et al., 2002).

\section{Season effects}

A major exogenous regulator of thyroid gland activity is the environmental temperature (Dickson, 1993), so an inverse relationship between ambient temperature and blood $\mathrm{TH}$ concentrations has been found in sheep (Valtorta et al., 1982; Webster et al., 1991; Starling et al., 2005) and goats (Colavita et al., 1983; Todini et al., 1992).

During heat stress, blood T3 and T4 concentrations, as well as metabolic rate, feed intake, growth and milk production were decreased (Valtorta et al., 1982; Silanikove, 2000). On the other hand, cold stress in ewes (Hocquette et al., 1992) ram lambs (Ekpe and Christopherson, 2000; Doubek et al., 2003) and shearing (Morris et al., 2000; Merchant and Riach, 2002) induced increases in blood TH levels. The seasonal pattern of blood TH levels often showed maximal values during winter (cold months) and minimal during summer (hot months) (Salem et al., 1991; Webster et al., 1991; Okab et al., 1993; Menegatos et al., 2006). However, contrasting results have been reported (Kloren et al., 1993; Rhind et al., 1998; Ashutosh et al., 2001; Yokus et al., 2006). In the Sahel desert, plasma T3 and T4 levels did not change significantly from the beginning of the cool season (December) until the end of the dry

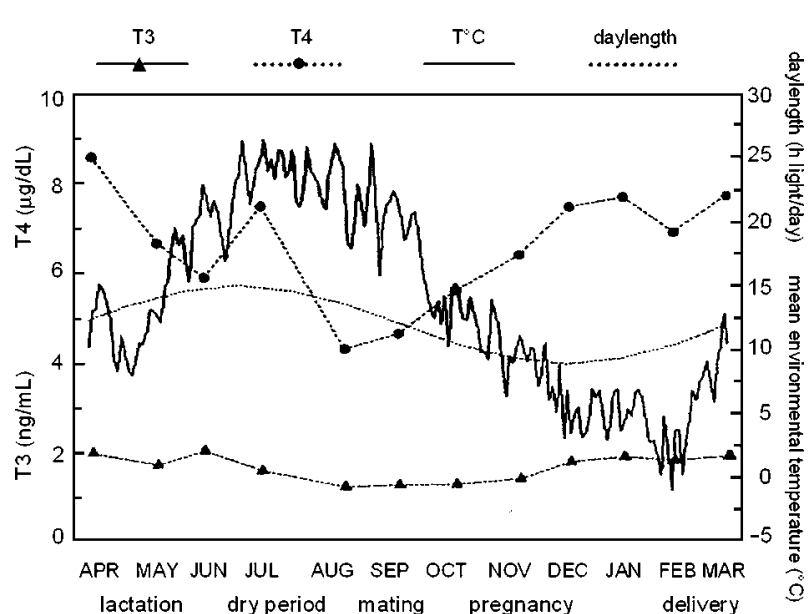

Figure 2 Circannual profiles of mean plasma T3 (3-5-3'-triiodothyronine) and T4 (thyroxine) in 20 female goats (local Umbrian population), mean environmental temperature, daylength and physiological state (modified from Lucaroni et al. (1989)).

warm season (May), but a highly significant rise of both hormones was observed at the onset of the humid warm season (June) (Assane and Sere, 1990). It can be supposed that an enhanced thyroid activity during the humid warm season in such environments is functional for the animals facing the increased availability of food (quantity and quality), following the seasons characterised by food shortage.

Blood TH concentrations were high in spring (increasing daylength) and low in autumn (decreasing daylength), which was not fully explained by the changes in environmental temperature (Figure 2; Buys et al., 1990; Todini et al., 1992; Rhind and McMillen, 1995: Clariget et al., 1998; Rhind et al., 2000; Taha et al., 2000; Villar et al, 2000a; Merchant and Riach, 2002; Souza et al., 2002; Blaszczyk et al., 2004; Zamiri and Khodaei, 2005; Menegatos et al., 2006; Todini et al., 2006). It seems that when the temperature ranges are not extreme (mild climate, indoor housing, shelter in the night time), the effect of photoperiod and season-dependent TH profiles (mainly related to the daylength changes) are present.

In Alpine and Saanen bucks exposed to artificial photoperiodic cycles, alternating 1 or 2 months of long days (LD: $16 \mathrm{~h}$ light and $8 \mathrm{~h}$ dark) to 1 or 2 months of short days (SD: $16 \mathrm{~h}$ dark and $8 \mathrm{~h}$ light), plasma T3 levels rapidly followed the photoperiodic changes, increasing during LD and decreasing during SD. The effects of daylength changes on plasma T4 concentrations were seen after a delay of several weeks and the T3:T4 ratio showed very marked variations, increasing during LD and decreasing during SD (Todini et al., 2006). Similar results were obtained by Lincoln et al. (1980) in rams submitted to an alternance of 16 weeks of SD and 16 weeks of LD. The mechanisms of the photoperiodic effects on peripheral TH are far from being elucidated. Additional data on actions of the photoperiod in the brain are scanty in small ruminants: TRH from hypothalamic 
perfusate samples of ewes only tended to be significantly higher during LD than during SD (Leshin and Jackson, 1987). Long days suppressed the expression of monodeiodinase gene in the hypothalamus of goats, thus limiting the local bioavailability of $\mathrm{TH}$, which should be related to the role of the thyroid gland in seasonal reproduction (Yasuo et al., 2006).

On the basis of the above-quoted studies, it is not possible to discriminate between the relative role of temperature and photoperiod on the seasonality of thyroid activity, in different environmental conditions. Moreover, when the feed intake is markedly seasonal, it becomes a major factor modifying the seasonal pattern of blood TH profiles.

\section{Nutrition effects}

T3 directly stimulates feed intake at the hypothalamic level (Kong et al., 2004), while on the other hand, the quantity and quality of food eaten is a major factor determining plasma concentrations of TH (Dauncey, 1990). Blood TH levels are considered to be good indicators of the nutritional status of an animal (Riis and Madsen, 1985) and were correlated with feed intake in ruminant species, including those that exhibit very marked seasonal cyclicity in feed intake, body weight and reproductive activity, e.g. deers (Ryg and Langvatn, 1982; Chao and Brown, 1984; Rhind et al., 1998).

Circulating TH concentrations seem better correlated with feed intake than adiposity status (McCann et al., 1992; Caldeira et al., 2007a and b).

Energy deprivation decreased concentrations of $\mathrm{T} 3$ and fT3 in adult sheep, while subsequent overnutrition increased them. Plasma total T3 concentrations significantly correlated with energy and nitrogen balances. Plasma rT3 levels showed an opposite pattern, increasing during energy deprivation and decreasing during overnutrition (Blum et al., 1980). Concentrate supplementation induced an increase of plasma T4 levels in lactating ewes (Shetaewi and Ross, 1991) and plasma T3 concentrations was higher in rams with high amounts of ingested energy and protein (Zhang et al., 2004). Following feed restriction or food deprivation, plasma $\mathrm{TH}$ concentrations were reduced in sheep (Naqvi and Rai, 1991; Wronska-Fortuna et al., 1993; Wester et al., 1995; Ekpe and Christopherson, 2000; Abecia et al., 2001; Rae et al., 2002). Feed-restricted animals also showed an earlier and more marked decline in plasma $\mathrm{TH}$ concentrations during the late summer/early autumn, compared with ad libitum fed animals (Rhind et al., 1998 and 2000).

Lactating Angora does and their kids supplemented with energy and protein (horse bean) had higher plasma $\mathrm{TH}$ concentrations than controls (Todini et al., 2005). Goats with a slightly higher energy intake showed higher plasma TH concentrations during the second half of gestation, and the decrease of plasma TH in mid- and late gestation was attenuated and delayed (Todini et al., 2007). These effects suggested that energy balance could play a major role in affecting the decrease in plasma TH levels usually observed at the end of gestation in small ruminants (see above). Furthermore, in the higher energy diet-fed goats, the variations of circulating T4 during different physiological states were not significant (Todini et al., 2007). Recently, no significant difference in the rates of type II and type III deiodinase activity in the skin or in blood TH concentrations was found between cashmere goats maintained at a different plane of nutrition (Rhind et al., 2006).

Selenium is present in deiodinase enzymes, and other selenoproteins play a protective role for the thyrocytes against damage by hydrogen peroxide produced for $\mathrm{TH}$ biosynthesis (Kohrle et al., 2005). Oral iodine and selenium supplements increased blood concentrations of TH in sheep, and selenium supplementation alone increased plasma T3 concentrations and decreased T4 concentrations (Bik, 2003). Following selenium supplementation, type I deiodinase activity decreased in the liver and increased in the pituitary, while pituitary type II deiodinase was unaffected, indicating that enzyme activity is homeostatically controlled when a sufficient amount of selenium is present, in order to ensure TH homeostasis (Chadio et al., 2006).

\section{Conclusion}

Changes of blood TH concentrations are an indirect measure of the changes in thyroid gland and extrathyreoidal deiodination activity. Many factors act simultaneously modulating thyroid gland activity and/or peripheral monodeiodination. Besides endogenous and environmental climatic factors, nutrition plays a primary role on thyroid gland activity and on blood TH concentrations. The physiological range of the endocrine responses to different conditions is very large, thus reference values are very difficult to obtain. Assay results must be carefully evaluated, not only for diagnostic and clinical purposes but also to evaluate the physiological states and responses of the animals. The systemic actions of TH justify their pivotal role in the mechanisms permitting the animals to adapt to the surrounding environment. New insights are gathered from investigations on the regulation of monodeiodinase activity, hence of TH bioavailability, in the central nervous system and at the peripheral level. Little is known about TH receptor expression and activity or about the targets at molecular levels, even in humans and rodents. The field of the non-genomic, rapid TH actions needs further research. Knowledge on such topics will possibly allow the monitoring and manipulation of thyroid physiology, in order to improve animal health, welfare and production (meat, milk, hair fibre).

\section{Acknowledgements}

The author wishes to thank Professor Alessandro Debenedetti and Professor Alessandro Malfatti for their guidance and 
encouragement, Dr Alessia Zicavo and Mr Diego Todini for their patient support.

\section{References}

Abecia JA, Zuniga 0 and Forcada $F$ 2001. Effect of melatonin treatment in spring and feed intake on wool growth and thyroxine secretion in Rasa Aragonesa ewes. Small Ruminant Research 41, 265-270.

Abecia JA, Valares JA and Forcada F 2005. The effect of melatonin treatment on wool growth and thyroxine secretion in sheep. Small Ruminant Research $56,265-270$.

Ain KB, Mori $Y$ and Refetoff S 1987. Reduced clearance rate of thyroxine-binding globulin (TBG) with increased sialylation: a mechanism for estrogen-induced elevation of serum TBG concentration. Journal of Clinical Endocrinology and Metabolism 65, 689-696.

Anderson GM, Connors JM, Hardy SL, Valent M and Goodman RL 2002. Thyroid hormones mediate steroid-independent seasonal changes in luteinizing hormone pulsatility in the ewe. Biology of Reproduction 66, 701-706.

Ashutosh, Dhanda OP and Kundu RL 2001. Effect of climate on the seasonal endocrine profile of native and crossbred sheep under semi-arid conditions. Tropical Animal Health and Production 33, 241-252.

Assane $M$ and Sere A 1990. Seasonal and gestational variations of triiodothyronine and thyroxine plasma-concentrations in Sahel Peulh ewe. Annales de Recherches Veterinaires 21, 285-289.

Bartalena L 1990. Recent achievements in studies on thyroid hormone-binding proteins. Endocrine Reviews 11, 47-64.

Bass J 1989. Effect of litter size, dietary protein content, ewe genotype and season on milk production and associated endocrine and blood metabolite status of ewes. Animal Breeding Abstracts 58, 275.

Bekeova E, Elecko J, Krajnicakova M, Hendrichovsky V and Maracek I 1991. Dynamics of changes in concentrations of cholesterol and thyroid and ovarian hormones in blood-serum during postparturient period of ewes. Veterinarni Medicina 36, 673-684.

Bianco AC and Kim BW 2006. Deiodinases: implications of the local control of thyroid hormone action. Journal of Clinical Investigation 116, 2571-2579.

Bianco AC, Salvatore D, Gereben B, Berry MJ and Larsen PR 2002. Biochemistry, cellular and molecular biology, and physiological roles of the iodothyronine selenodeiodinases. Endocrine Reviews 23, 38-89.

Bik DE 2003. Influence of selenium and iodine supplementation on thyroid hormone concentrations in the blood serum of sheep. Medycyna Weterynaryjna 59, 1126-1129.

Billings HJ, Viguié C, Karsch FJ, Goodman RL, Connors JM and Anderson GM 2002. Temporal requirements of thyroid hormones for seasonal changes in $L H$ secretion. Endocrinology 143, 2618-2625.

Blaszczyk B, Udala J and Gaczrzewicz D 2004. Changes in estradiol, progesterone, melatonin, prolactin and thyroxine concentrations in blood plasma of goats following induced estrus in and outside the natural breeding season. Small Ruminant Research 51, 209-219.

Blum JW, Gingins M, Vitins P and Bickel H 1980. Thyroid hormone levels related to energy and nitrogen balance during weight loss and regain in adult sheep. Acta Endocrinologica 93, 440-447.

Buys N, Peeters R, De Clerck B, Van Isterdael J, Kuhn ER and Decuypere E 1990. Seasonal variations in prolactin, growth hormone and thyroid hormones and the prolactin surge at ovulation do not affect litter size of ewes during pregnancy in the oestrous or the anoestrous season. Journal of Reproduction and Fertility $90,47-53$.

Cabello $\mathrm{G}$ and Wrutniak C 1986. Plasma free and total iodothyronine levels in the newborn lamb. Physiological consideration. Reproduction, Nutrition, Development 26, 1281-1288.

Cabello $\mathrm{G}$ and Wrutniak C 1990. Thyroid function in the newborn lamb. Physiological approach of the mechanisms inducing the changes in plasma thyroxine, free thyroxine and triiodothyronine concentrations. Journal of Developmental Physiology 13, 25-32.

Caldeira RM, Belo AT, Santos CC, Vazques MI and Portugal AV 2007a. The effect of body condition score on blood metabolites and hormonal profiles in ewes. Small Ruminant Research 68, 233-241.
Caldeira RM, Belo AT, Santos CC, Vazques MI and Portugal AV 2007b. The effect of long-term feed restriction and over-nutrition on body condition score, blood metabolites and hormonal profiles in ewes. Small Ruminant Research $68,242-255$.

Capen CC and Martin SL 1989. The thyroid gland. In Veterinary endocrinology and reproduction, fourth edition (ed. LE MCDonald, MH Pineda), pp. 58-91. Lea and Febiger, Philadelphia, PA.

Celi P, Seren E, Celi R, Parmeggiani A and Di Trana A 2003. Relationships between blood hormonal concentrations and secondary fibre shedding in young cashmere-bearing goats at their first moult. Animal Science 77, 371-381.

Chadio SE, Kotsampasi BM, Menegatos JG, Zervas GP and Kalogiannis DG 2006. Effect of selenium supplementation on thyroid hormone levels and selenoenzyme activities in growing lambs. Biological Trace Element Research 109, 145-154.

Chao CC and Brown RD 1984. Seasonal relationships of thyroid, sexual and adrenocortical hormones to nutritional parameters and climatic factors in white-tailed deer (Odocoileus virginianus) of south Texas. Comparative Biochemistry and Physiology - Part A: Physiology 77, 299-306.

Chopra IJ, Sack J and Fisher DA 1975. 3,3', 5'-Triiodothyronine (Reverse T3) and $3,3,5^{\prime}$-Triiodothyronine (T3) in fetal and adult sheep: studies on metabolic clearance rates, production rates, serum binding, and thyroidal content relative o thyroxine. Endocrinology 97, 1080-1088.

Chopra IJ, Solomon DH, Chopra U, Wu SY, Fisher DA and Nakamura Y 1978. Pathways of metabolism of thyroid hormones. Recent Progress in Hormone Research 34, 521-567.

Chopra IJ, Huang TS, Beredo A, Solomon DH, Chua Teco GN and Mead JF 1985. Evidence for an inhibitor of extrathyroidal conversion of thyroxine to $3,5,3^{\prime}$ triiodothyronine in sera of patients with nonthyroidal illnesses. Journal of Clinical Endocrinology and Metabolism 60, 666-672.

Christianson D, Roti E, Vagenakis AG and Braverman LE 1981. The sex related difference in serum thyrotropin concentration is androgen mediated. Endocrinology 108, 529-535.

Clariget RP, Forsberg M and Rodriguez-Martinez H 1998. Seasonal variation in live weight, testes size, testosterone, $\mathrm{LH}$ secretion, melatonin and thyroxine in Merino and Corriedale rams in a subtropical climate. Acta Veterinaria Scandinavica 39, 35-47.

Colavita GP and Malfatti A 1989. Hematic concentration of thyroid hormones $\mathrm{T} 3$ and T4 in goats at the beginning of the seasonal sexual activity. Atti della Società Italiana delle Scienze Veterinarie 43, 467-471.

Colavita GP, Debenedetti A, Ferri C, Lisi C and Lucaroni A 1983. Blood thyroid hormone concentrations by the domestic goat: seasonal and age-related variations. Bollettino della Società Italiana di Biologia Sperimentale 49, 779-785.

Collin A, Cassy S, Buyse J, Decuypere E and Damon M 2005. Potential involvement of mammalian and avian uncoupling proteins in the thermogenic effect of thyroid hormones. Domestic Animal Endocrinology 29, 78-87.

Darby CJ, Clarke L, Lomax MA and Symonds ME 1996. Brown adipose tissue and liver development during early postnatal life in hand-reared and ewereared lambs. Reproduction Fertility and Development 8, 137-145.

Davis PJ, Tillman HC, Davis FB and Wehling M 2002. Comparison of the mechanisms of nongenomic actions of thyroid hormone and steroid hormones. Journal of Endocrinological Investigation 25, 377-388.

Davis PJ, Davis FB and Cody V 2005. Membrane receptors mediating thyroid hormone action. Trends in Endocrinology and Metabolism 16, 429-435.

Dauncey MJ 1990. Thyroid hormones and thermogenesis. Proceedings of the Nutrition Society 49, 203-215.

De Leo V, la Marca A, Lanzetta D and Morgante G 1998. Thyroid function in early pregnancy I: Thyroid-stimulating hormone response to thyrotropinreleasing hormone. Gynecological Endocrinology 12, 191-196.

Dickson WM 1993. Endocrine glands. In: Duke's physiology of domestic animals, 11th edition (ed. MJ Swenson and WO Reece), pp. 629-664. Comstock Publishers Association, Ithaca and London.

Donald GE, Langlands JP, Bowles JE and Smith AJ 1994. Subclinical selenium insufficiency. 5. Selenium status and the growth and wool production of sheep supplemented with thyroid hormones. Australian Journal of Experimental Agriculture 34, 13-18.

Doubek J, Slosarkova S, Fleischer P, Malà G and Skrivanek M 2003. Metabolic and hormonal profiles of potentiated cold stress in lambs during early postnatal period. Czech Journal of Animal Science 48, 403-411. 
Todini

Dussault JH, Hobel CJ and Fisher DA 1971. Maternal and fetal thyroxine secretion during pregnancy in the sheep. Endocrinology 88, 47-51.

Dwyer CM and Lawrence AB 2005. A review of the behavioural and physiological adaptations of hill and lowland breeds of sheep that favour lamb survival. Applied Animal Behaviour Science 92, 235-260.

Dwyer CM and Morgan A 2006. Maintenance of body temperature in the neonatal lamb: Effects of breed, birth weight, and litter size. Journal of Animal Science 84, 1093-1101.

Ekpe ED and Christopherson RJ 2000. Metabolic and endocrine responses to cold and feed restriction in ruminants. Canadian Journal of Animal Science 80, 87-95.

Emre $Z$ and Garmo G 1985. Plasma thyroxine through parturition and early lactation in goats fed silage of grass and rape. Acta Veterinaria Scandinavica 26, 417-418.

Fallah-Rad AH and Connor ML 1999. Relationships of thyroid hormones, IGF-I and testosterone in breeds of ram lambs with low and high prolificacies. Canadian Journal of Animal Science 79, 441-448.

Federman DD, Robbins J and Rall JE 1958. Effects of methyl testosterone on thyroid function, thyroxine metabolism and thyroxine-binding protein. Journal of Clinical Investigations 37, 1024-1030.

Firat A, Ozpinar A, Serpek B and Haliloglu S 2005. Comparisons of serum somatotropin, 3,5,3'-triiodothyronine, thyroxine, total protein and free fatty acid levels in newborn Sakiz lambs separated from or suckling their dams. Annals of Nutrition and Metabolism 49, 88-94.

Fisher DA, Chopra IJ and Dussault JH 1972. Extrathyroidal conversion of thyroxine to triiodothyronine in sheep. Endocrinology 91, 1141-1144.

Follett BK and Potts C 1990. Hypothyroidism affects reproductive refractoriness and the seasonal oestrous period in Welsh Mountain ewes. Journal of Endocrinology 127, 103-109.

Forhead AJ, Li J, Gilmour RS and Fowden AL 1998. Control of hepatic insulinlike growth factor II gene expression by thyroid hormones in fetal sheep near term. American Journal of Physiology - Endocrinology and Metabolism 275, E149-E156.

Forhead AJ, Li J, Saunders JC, Dauncey MJ, Gilmour RS and Fowden AL 2000. Control of ovine hepatic growth hormone receptor and insulin-like growth factor I by thyroid hormones in utero. American Journal of Physiology Endocrinology and Metabolism 278, E1166-E1174.

Forhead AJ, Li J, Gilmour RS, Dauncey MJ and Fowden AL 2002. Thyroid hormones and the mRNA of the GH receptor and IGFs in skeletal muscle of fetal sheep. American Journal of Physiology - Endocrinology and Metabolism 282, E80-E86.

Forhead AJ, Poore KR, Mapstone J and Fowden AL 2003. Developmental regulation of hepatic and renal gluconeogenic enzymes by thyroid hormones in fetal sheep during late gestation. The Journal of Physiology 548, 941-947.

Forhead AJ, Curtis K, Kaptein E, Visser TJ and Fowden AL 2006. Developmental control of iodothyronine deiodinases by cortisol in the ovine fetus and placenta near term. Endocrinology 147, 5988-5994.

Fowden AL, Mapstone J and Forhead AJ 2001. Regulation of glucogenesis by thyroid hormones in fetal sheep during late gestation. Journal of Endocrinology $170,461-469$.

Friesema EC, Jansen J, Milici C and Visser TJ 2005. Thyroid hormone transporters. Vitamins and Hormones 70, 137-167.

Galton VA 2005. The roles of the iodothyronine deiodinases in mammalian development. Thyroid 15, 823-834.

Glinoer D 2001. Pregnancy and iodine. Thyroid 11, 471-481.

Greenspan FS 2001. The thyroid gland. In: Basic and clinical endocrinology, sixth edition (ed. FS Greenspan and DG Gardner), pp. 201-272. Lange/ McGraw Hill, New York.

Hart DS 1957. Stimulation of wool growth by thyroxine implantation. New Zealand Journal of Science and Technologies 38, 871-880.

Hennemann $G$, Docter $R$, Friesema EC, de Jong $M$, Krenning EP and Visser TJ 2001. Plasma membrane transport of thyroid hormones and its role in thyroid hormone metabolism and bioavailability. Endocrine Reviews 22, 451-476.

Hernandez JA, Hallford DM and Wells NH 2003. Ovarian cyclicity in thyroidsuppressed ewes treated with propylthiouracil immediately before onset of seasonal anestrus. Journal of Animal Science 81, 29-34.
Hernandez A, Martinez ME, Fiering S, Galton VA and St Germain D 2006. Type 3 deiodinase is critical for the maturation and function of the thyroid axis. Journal of Clinical Investigation 116, 476-484.

Hiroi $Y$, Kim HH, Ying $H$, Furuya $F$, Huang ZH, Simoncini T, Noma K, Ueki $K$, Nguyen NH, Scanlan TS, Moskowitz MA, Cheng SY and Liao JK 2006. Rapid nongenomic actions of thyroid hormone. Proceedings of the National Academy of Sciences of the United States of America 103, 14104-14109.

Hoath SB, Laksmanan J, Scott SM and Fisher DA 1983. Effect of thyroid hormones on epidermal growth factor concentration in neonatal mouse skin. Endocrinology 112, 308-314.

Hocquette JF, Vermorel M, Bouix J, Anglaret $Y$, Donnat JP, Leoty C, Meyer M and Souchet $R$ 1992. Effects of cold, wind and rain on energy-expenditure and thermoregulation of ewes from 7 genetic types. Genetics Selection Evolution $24,147-169$

Hynd PI 1994. Follicular determinants of the length and diameter of wool fibres. 2. Comparison of sheep differing in thyroid hormone status. Australian Journal Agricultural Research 45, 1149-1157.

Jana NR and Bhattacharya S 1994. Binding of thyroid hormone to the goat testicular Leydig cell induces the generation of a proteinaceous factor which stimulates androgen release. Journal of Endocrinology 143, 549-556.

Jana NR, Halder S and Bhattacharya S 1996. Thyroid hormone induces a 52 $\mathrm{kDa}$ soluble protein in goat testis Leydig cell which stimulates androgen release. Biochimica et Biophysica Acta 1292, 209-214.

Jansen HT, Lubbers LS, Macchia E, DeGroot LJ and Lehman MN 1997. Thyroid hormone receptor $(\alpha)$ distribution in hamster and sheep brain: colocalization in gonadotropin-releasing hormone and other identified neurons. Endocrinology 138, 5039-5047.

Kaiser CA, Goumaz MO and Burger AG 1986. In vivo inhibition of the $5^{\prime}$ deiodinase type II in brain cortex and pituitary by reverse triiodothyronine. Endocrinology 119, 762-770.

Karsch FJ, Dahl GE, Hachigian TM and Thrun LA 1995. Involvement of thyroid hormones in seasonal reproduction. Journal of Reproduction and Fertility Supplement 49, 409-422.

Khan JR and Ludri RS 2002a. Hormone profiles during periparturient period in single and twin fetus bearing goats. Asian-Australasian Journal of Animal Sciences 15, 346-351.

Khan JR and Ludri RS 2002b. Hormone profile of crossbred goats during the periparturient period. Tropical Animal Health and Production 34, 151-162.

Klein AH, Oddie TH and Fisher DA 1978. Effect of parturition on serum iodothyronine concentrations in fetal sheep. Endocrinology 103, 1453-1457.

Kloren WRL, Norton BW and Waters MJ 1993. Fleece growth in Australian cashmere goats. III. The seasonal patterns of cashmere and hair growth, and association with growth hormone, prolactin and thyroxine in blood. Australian Journal of Agricultural Research 44, 1035-1050.

Kong WM, Martin NM, Smith KL, Gardiner JV, Connoley IP, Stephens DA, Dhillo WS, Ghatei MA, Small CJ and Bloom SR 2004. Triiodothyronine stimulates food intake via the hypothalamic ventromedial nucleus independent of changes in energy expenditure. Endocrinology 145, 5252-5258.

Kohrle J 1999. Local activation and inactivation of thyroid hormones: the deiodinase family. Molecular and Cellular Endocrinology 151, 103-119.

Kohrle J, Jakob F, Contempré B and Dumont JE 2005. Selenium, the thyroid, and the endocrine system. Endocrine Reviews 26, 944-984.

Lee GJ, Thornberry KJ and Williams AJ 2001. The use of thyroxine to reduce average fibre diameter in fleece wool when feed intake is increased. Australian Journal of Experimental Agriculture 41, 611-617.

Leshin LS and Jackson GL 1987. Effect of photoperiod and morphine on plasma prolactin concentration and thyrotropin-releasing hormone secretion in the ewe. Neuroendocrinology 46, 461-467.

Lincoln GA, Klandorf $H$ and Anderson N 1980. Photoperiodic control of thyroid function and wool and horn growth in rams and the effect of cranial sympathectomy. Endocrinology 107, 1543-1548.

Lucaroni A and Todini L 1989. Thyroid hormones blood concentration during pregnancy, delivery and lactation by the goat. Atti della Società Italiana della Scienze Veterinarie 43, 473-477.

Lucaroni A, Todini L, Malfatti A and Debenedetti A 1989. Thyroid hormones blood level by the goat. Annual and diurnal variations. Effect of different physiological states. In: Atti del XXIV Simposio Internazionale di 
Zootecnia: Piccoli Ruminanti oggi (ed. GF Greppi and M Corti), pp. 91-104. Società Italiana per il Progresso della Zootecnia, Milano.

Maddocks S, Chandrasekhar Y and Setchell BP 1985. Effect on wool growth of thyroxine replacement in thyroidectomized Merino rams. Australian Journal of Biological Science 38, 405-410.

Manalu W, Sumaryadi MY and Kusumorini N 1997. Maternal serum concentrations of total triiodothyronine, tetraiodothyronine and cortisol in different status of pregnancy during late pregnancy in Ettawah-cross does. Asian-Australasian Journal of Animal Sciences 10, 385-390.

Maurenbrecher S and Barrell GK 2003. Suppression of thyroid gland function and its effects on the breeding season of Coopworth ewes. New Zealand Journal of Agricultural Research 46, 1-7.

McDonald BJ, Stocks DC, Connell JA and Hoey WA 1988. Thyroxine concentration in maternal and foetal plasma during pregnancy in Australian feral goats. Journal of Agricultural Science, Cambridge 110, 25-30.

McCann JP, Bergman EN and Beermann DH 1992. Dynamic and static phases of severe dietary obesity in sheep: food intakes, endocrinology and carcass and organ chemical-composition. Journal of Nutrition 122, 496-505.

Menegatos J, Goulas C and Kalogiannis D 2006. The productivity, ovarian and thyroid activity of ewes in an accelerated lambing system in Greece. Small Ruminant Research 65, 209-216.

Merchant $\mathrm{M}$ and Riach DJ 2002. The effect of plane of nutrition and shearing on the pattern of the moult in Scottish Cashmere goats. Animal Science 74, 177-188.

Mitin V, Mikulec $\mathrm{K}$ and Karadjole I 1986. Thyroid hormones and insulin concentration in sheep. Veterinarski Arhiv 55, S73-S75.

Moreno M, Lombardi A, Beneduce L, Silvestri E, Pinna G, Goglia F and Lanni A 2002. Are the effects of $T-3$ on resting metabolic rate in euthyroid rats entirely caused by T-3 itself? Endocrinology 143, 504-510.

Morris ST, McCutcheon SN and Revell DK 2000. Birth weight responses to shearing ewes in early to mid gestation. Animal Science 70, 363-369.

Mostyn A, Wilson V, Dandrea J, Yakubu DP, Budge H, Alves-Guerra MC, Pecqueur C, Miroux B, Symonds ME and Stephenson T 2003. Ontogeny and nutritional manipulation of mitochondrial protein abundance in adipose tissue and the lungs of postnatal sheep. British Journal of Nutrition 90 323-328.

Naqvi SMK and Rai AK 1991. Influence of dietary energy-level on sheep for mutton during winter. 2. Effect on cardiorespiratory responses, rectal temperature, some blood metabolites, enzymes and thyroidal hormones. Indian Journal of Animal Sciences 61, 1126-1131.

Nathanielsz PW, Silver M and Comline RS 1973. Plasma tri-iodothyronine concentration in the foetal and newborn lamb. Journal of Endocrinology 58, 683-684.

Nicholls TJ, Goldsmith AR and Dawson A 1988a. Photorefractoriness in birds and comparison with mammals. Physiological Reviews 68, 133-176.

Nicholls TJ, Follett BK, Goldsmith AR and Pearson H 1988b. Possible homologies between photorefractoriness in sheep and birds: the effect of thyroidectomy on the length of the ewe's breeding season. Reproduction Nutrition Development 28, 375-385.

Nicol F, Lefranc H, Arthur JR and Trayhurn P 1994. Characterization and postnatal-development of $5^{\prime}$-deiodinase activity in goat perirenal fat. American Journal of Physiology 267, R144-R149.

Okab AB, Elebanna IM, Mekkawy MY, Hassan GA, Elnouty FD and Salem MH 1993. Seasonal-changes in plasma thyroid-hormones, total lipids, cholesterol and serum transaminases during pregnancy and at parturition in barki and rahmani ewes. Indian Journal of Animal Sciences 63, 946-951.

Okamoto R and Leibfritz D 1997. Adverse effect of reverse triiodothyronine on cellular metabolism as assessed by ${ }^{1} \mathrm{H}$ and ${ }^{31} \mathrm{P}$ NMR spectroscopy. Research in Experimental Medicine 197, 211-217.

Parkinson TJ and Follett BK 1994. Effect of thyroidectomy upon seasonality in rams. Journal of Reproduction and Fertility 101, 51-58.

Parkinson TJ, Douthwaite JA and Follett BK 1995. Responses of prepubertal and mature rams to thyroidectomy. Journal of Reproduction and Fertility 104 , $51-56$.

Peeters R, Buys N, Pauwels T, Kuhn ER, Decuypere E, Siau 0 and Van Isterdael J 1989. Relationship between the thyroidal and gonadal axes during the estrus cycle of ewes of different breeds and ages. Reproduction Nutrition Development 29, 237-245.
Peeters R, Buys N, Vanmontfort D, van Isterdael J, Decuypere E and Kuhn ER 1992. Preferential release of triiodothyronine following stimulation by thyrotropin or thyrotropin-releasing hormone in sheep of different ages. Journal of Endocrinology 132, 93-100.

Puchala R, Pierzynowski SG and Sahlu T 1998. Effects of methionine and hormones on amino acid concentration in the skin of Angora goats. Small Ruminant Research 29, 93-102.

Puchala R, Prieto I, Banskalieva V, Goetsch AL, Lachica M and Sahlu T 2001. Effects of bovine somatotropin and thyroid hormone levels, body weight gain, and mohair fiber growth of Angora goats. Journal of Animal Science 79, 2913-2919.

Rae MT, Rhind SM, Miller DW and Brooks AN 2002. Maternal undernutrition alters triiodothyronine concentrations and pituitary response to $\mathrm{GnRH}$ in fetal sheep. Journal of Endocrinology 173, 449-455.

Rhind S and McMillen SR 1995. Seasonal changes in systemic hormone profiles and their relationship to patterns of fibre growth and moulting in goats of contrasting genotypes. Australian Journal of Agricultural Research 46, 1273-1283.

Rhind SM and McMillen SR 1996. Effects of methylthiouracil treatment on the growth and moult of cashmere fibre in goats. Animal Science 62, 513-520.

Rhind SM and Kyle CE 2004. Skin deiodinase profiles and associated patterns of hair follicle activity in cashmere goats of contrasting genotypes. Australian Journal of Agricultural Research 55, 443-448.

Rhind SM, Bass J, Doney JM and Hunter EA 1991. Effect of litter size on the milk production, blood metabolite profiles and endocrine status of ewes lambing in January and April. Animal Production 53, 71-80.

Rhind SM, McMillen SR, Duff E, Hirst D and Wright S 1998. Seasonality of meal patterns and hormonal correlates in red deer. Physiology \& Behavior 65 , 295-302.

Rhind SM, McMillen SR, Duff E, Kyle CE and Wright S 2000. Effect of long-term feed restriction on seasonal endocrine changes in Soay sheep. Physiology \& Behavior 71, 343-351.

Rhind SM, Kyle CE and Duff El 2004. Effects of season and of manipulation of circulating prolactin concentrations on deiodinase activity in cashmere goat skin. Australian Journal of Agricultural Research 55, 211-221.

Rhind SM, Kyle CE, Riach DJ and Duff El 2006. Effects of nutrition on hormone profiles and patterns od deiodinase activity in the skin and associated patterns of hair follicle activity and moult in cashmere goats. Animal Science 82, 723-730.

Riis PM and Madsen A 1985. Thyroxine concentration and secretion rates in relation to pregnancy, lactation and energy balance in goats. Journal of Endocrinology 107, 421-427.

Ryder ML 1979. Thyroxine and wool follicle activity. Animal Production 28, 109-114.

Ryg $M$ and Langvatn $R$ 1982. Seasonal changes in weight gain, growth hormone, and thyroid hormones in male red deer (Cervus elaphus atlanticus). Canadian Journal of Zoology 60, 2577-2581.

Salem MH, Elsherbiny AA, Khali MH and Yousef MK 1991. Diurnal and seasonal rhythm in plasma-cortisol, triiodothyronine and thyronine as affected by the wool coat in barki sheep. Indian Journal of Animal Sciences 61, 946-951.

Santini F, Chopra IJ, Hurd RE and Teco GNC 1992. A study of the characteristics of hepatic iodothyronine $5^{\prime}$-monodeiodinase in various vertebrate species. Endocrinology 131, 830-834.

Schermer SJ, Bird JA, Lomax MA, Sheperd DAL and Symonds ME 1996. Effect of fetal thyroidectomy on brown adipose tissue and thermoregulation in newborn lambs. Reproduction, Fertility and Development 8, 995-1002.

Sensky PL, Roy CH, Barnes RJ and Heath MF 1994. Changes in fetal thyroid hormone levels in adrenalectomized fetal sheep following continuous cortisol infusion $72 \mathrm{~h}$ before delivery. Journal of Endocrinology 140, 79-83.

Shetaewi MM and Ross TT 1991. Effects of concentrate supplementation and lasalocid on serum chemistry and hormone profiles in Rambouillet ewes. Small Ruminant Research 4, 365-377.

Silanikove N 2000. Effects of heat stress on the welfare of extensively managed domestic ruminants. Livestock Production Science 67, 1-18.

Silva JE 2005. Thyroid hormone and the energetic cost of keeping body temperature. Bioscience Reports 25, 129-148. 
Todini

Slebodzinski A 1972. Acute depletion of the hormonal-iodine stores from the thyroid gland after birth in lambs. Journal of Endocrinology 53, 195-200.

Souza MIL, Bicudo SD, Uribe-Velasquez LF and Ramos AA 2002. Circadian and circannual rhythms of T3 and T4 secretions in Polwarth-Ideal rams. Small Ruminant Research 46, 1-5.

Starling JMC, da Silva RG, Negrao JA, Maia ASC and Bueno AR 2005. Seasonal variation of thyroid hormones and cortisol of sheep in tropical environment. Revista Brasileira de Zootecnia 34, 2064-2073.

Symonds ME, Mostyn A, Pearce S, Budge $H$ and Stephenson T 2003. Endocrine and nutritional regulation of fetal adipose tissue development. Journal of Endocrinology 179, 293-299.

Taha TA, Abdel-Gawad El and Ayoub MA 2000. Monthly variations in some reproductive parameters of Barki and Awassi rams throughout 1 year under subtropical conditions. 1. Semen characteristics and hormonal levels. Animal Science 71, 317-324.

Thrun LA, Dahl GE, Evans NP and Karsch FJ 1996. Time-course of thyroid hormone involvement in the development of anestrus in the ewe. Biology of Reproduction 55, 833-837.

Thrun LA, Dahl GE, Evans NP and Karsch FJ 1997a. A critical period for thyroid hormone action on seasonal changes in reproductive neuroendocrine function in the ewe. Endocrinology 138, 3402-3409.

Thrun LA, Dahl GE, Evans NP and Karsch FJ 1997b. Effect of thyroidectomy on maintenance of seasonal reproductive suppression in the ewe. Biology of Reproduction 56, 1035-1040.

Todini L, Lucaroni A, Malfatti A, Debenedetti A and Costarelli S 1992. Malefemale differences in the annual profiles of the thyroid hormones blood level by the goat. Atti della Società Italiana della Scienze Veterinarie 46, 169-173.

Todini L, Malfatti A, Barbato 0, Trabalza-Marinucci M, Acuti G, Antonini M and Debenedetti A 2005. Plasma thyroid hormones, fibre characteristics and hair follicle activity in angora kids: effects of supplementation with horse bean (Vicia faba minor). Atti della Società Italiana della Scienze Veterinarie 59, 39-40.

Todini L, Delgadillo JA, Debenedetti A and Chemineau P 2006. Plasma total T3 and T4 concentrations in bucks as affected by photoperiod. Small Ruminant Research 65, 8-13.

Todini L, Malfatti A, Valbonesi A, Trabalza-Marinucci M and Debenedetti A 2007. Plasma total T3 and T4 concentrations in goats at different physiological stages, as affected by the energy intake. Small Ruminant Research 68, 285-290.

Tucker HA 1994. Lactation and its hormonal control. In:The physiology of reproduction, second edition (ed. E Knobil and JD Neil), pp. 1065-1098. Raven Press, New York.

Tucker HA 2000. Hormones, mammary growth, and lactation: a 41-year perspective. Journal of Dairy Science 83, 874-884.

Utiger RD 1995. The thyroid: physiology, thyrotoxicosis, hypothyroidism, and the painful thyroid. In:Endocrinology and metabolism, third edition (ed. P Felig, JD Baxter and LA Frohman), pp. 435-519. McGraw-Hill Inc., New York.

Valtorta S, Hahn L and Johnson HD 1982. Effect of high ambient temperature (35 degrees), and feed intake on plasma T4 levels in sheep. Proceedings of the Society for Experimental Biology and Medicine 169, 260-265.

Velasquez LFU, Souza MIL, Oba E and Ramos AD 1997. Circadian rhythms of plasma triiodothyronine (T-3) and thyroxine (T-4) in ideal ewe sheep during seasonal anoestrus. Revista da Sociedade Brasileira de Zootecnia 26, 508-513.

Viguié C, Battaglia DF, Krasa HB, Thrun LA and Karsch FJ 1999. Thyroid hormones act primarily within the brain to promote the seasonal inhibition of luteinizing hormone secretion in the ewe. Endocrinology 140, 1111-1117.

Villar D, Rhind SM, Dicks P, McMillen SR, Nicol F and Arthur JR 1998. Effect of propylthiouracil-induced hypothyroidism on thyroid hormone profiles and tissue deiodinase activity in cashmere goats. Small Ruminant Research 29, 317-324.
Villar D, McMillen SR, Dicks P and Rhind SM 2000a. The roles of thyroid hormones and prolactin in the control of fibre moult and associated changes in hair follicle activities in cashmere goats. Australian Journal of Agricultural Research 51, 407-414

Villar D, Nicol F, Arthur JR, Dicks P, Cannavan A, Kennedy DG and Rhind SM 2000b. Type II and type III monodeiodinase activities in the skin of untreated and propylthiouracil-treated cashmere goats. Research in Veterinary Science 68, 119-123.

Walkden-Brown SW, Davidson RH, Milton JTB and Martin GB. 1996. Thyroidectomy late in the breeding season advances the onset of seasonal anovulation in cashmere goats. Proceedings of the 13th international congress on animal reproduction, Sydney, Australia, P1.19.

Wartofsky $L$ and Burman KD 1982. Alterations in thyroid function in patients with systemic illness: the "euthyroid sick syndrome". Endocrine Reviews 3 , 164-217.

Webster JR, Moenter SM, Woodfill CJ and Karsh FJ 1991. Role of the thyroid gland in seasonal reproduction. II. Thyroxine allows a season-specific suppression of gonadotropin secretion in sheep. Endocrinology 129, 176-183. Wester TJ, Britton RA, Klopfenstein TJ, Ham GA, Hickok DT and Krehbiel CR 1995. Differential effects of plane of protein or energy nutrition on visceral organs and hormones in lambs. Journal of Animal Science 73 1674-1688.

Williams CC, Calmes KJ, Fernandez JM, Stanley CC, Lovejoy JC, Bateman HG, Gentry LR, Gantt DT and Harding GD 2004. Glucose metabolism and insulin sensitivity in Gulf Coast native and Suffolk ewes during late gestation and early lactation. Small Ruminant Research 54, 167-171.

Wronska-Fortuna D, Sechman A, Niezgoda J and Bobek S 1993. Modified responses of circulating cortisol, thyroid hormones, and glucose to exogenous corticotropin and thyrotropin-releasing hormone in food-deprived sheep. Pharmacology Biochemistry and Behavior 45, 601-606.

Wrutniak-Cabello C, Casas F and Cabello G 2001. Thyroid Hormone action in mitochondria. Journal of Molecular Endocrinology 26, 67-77.

Wu SY, Polk D, Wong S, Reviczky A, Vu R and Fisher DA 1992. Thyroxine sulfate is a major thyroid hormone metabolite and a potential intermediate in the monodeiodination pathways in fetal sheep. Endocrinology 131 1751-1756.

Wu SY, Green WL, Huang WS, Hays MT and Chopra IJ 2005. Alternate pathways of thyroid hormone metabolism. Thyroid 15, 943-958.

Wu SY, Polk DH, Huang WS, Green WL, Thai B and Fisher DA 2006. Fetal-tomaternal transfer of thyroid hormone metabolites in late gestation in sheep. Pediatric Research 59, 102-106.

Yasuo S, Nakao N, Ohkura S, ligo M, Hagiwara S, Goto A, Ando H, Yamamura T, Watanabe M, Watanabe T, Oda S, Maeda K, Lincoln GA, Okamura H, Ebihara $S$ and Yoshimura $T$ 2006. Long-day suppressed expression of type 2 deiodinase gene in the mediobasal hypothalamus of the Saanen goat, a short-day breeder: implications for seasonal window of thyroid hormone action on reproductive neuroendocrine axis. Endocrinology 147, 432-440.

Yildiz A, Balikci E and Gurdogan F 2005. Changes in some serum hormonal profiles during pregnancy in single- and twin-foetus-bearing Akkaraman sheep. Medycyna Weterynaryjna 61, 1138-1141.

Yokus B, Cakir DU, Kanay Z, Gulten T and Uysal E 2006. Effects of seasonal and physiological variations on the serum chemistry, vitamins and thyroid hormone concentrations in Sheep. Journal of Veterinary Medicine - Series A 53, 271-276.

Zamiri MJ and Khodaei HR 2005. Seasonal thyroidal activity and reproductive characteristics of Iranian fat-tailed rams. Animal Reproduction Science 88, 245-255.

Zhang S, Blache D, Blackberry MA and Martin GB 2004. Dynamics of the responses in secretion of luteinizing hormone, leptin and insulin following an acute increase in nutrition in mature male sheep. Reproduction, Fertility and Development 16, 823-829. 